\title{
PEMBELAJARAN BAHASA RESEPTIF BAGI ANAK AUTISME DENGAN PENDEKATAN DISCRETE TRIAL TRAINING(DTT)
}

\author{
Rofi Badari \\ SD Negeri 33 Pangkalpinang \\ badari.rofi@yahoo.com
}

\begin{abstract}
Abstrak
Penelitian ini merupakan penelitian tindakan kelas berupa penerapan metode discrete trial training (DTT) dalam upaya meningkatkan bahasa reseptif anak dengan autism dalam belajar. Penelitian ini dilaksanakan pada kelas awal di kelas 1 SD Negeri 33 pangkalpinang. Penelitian ini akumulatif selama 10 jam pelajaran yang terbagi dalam 5 kali pertemuan. Pertemuan dimulai siklus I tanggal 2 - 3 Oktober 2015, siklus II dilaksanakan pada tanggal 9-10 Oktober 2015 dan siklus II dilaksanakan pada tanggal 6 Nopember 2015. Ketercapaian dilihat berdasar pada penguasaaan materi ditiap tahap pembelajaran. Setiap stimulus dan respon anak didokumentasikan untuk mengetahui tingkat pengulangan dengan semakin sedikit pengulangan menyatakan pemahaman anak. Hasil yang diperoleh pada siklus I subyek Re dapat menguasai 6 dari 10 materi dan subyek RI menguasai 5 materi dari 10 materi, pengulangan stimulus lebih dari 3 kali. Siklus II dilaksanakan dengan merubah stimulus berupa peningkatan reward hasil kegiatan subyek Re dapat menguasai 7 dari 10 materi dan subyek RI menguasai 6 materi dari 10 materi, pengulangan stimulus rata rata 2 kali. Siklus III modifikasi berupa penyesuaian tekanan instruksi yang disesuaikan dengan respon anak. subyek Re dapat menerima respon dengan nada yang lembut menguasai 8 dari 10 materi dan subyek ri menguasai 7 materi dari 10 materi, pengulangan stimulus rata rata dibawah 2 kali. Dengan melihat pengulangan stimulus singkat dan respon yang cepat dan benar maka pembelajaran dianggap berhasil.
\end{abstract}

Kata Kunci: Stimulus, respon, metode Discrete trial training.

\section{PENDAHULUAN}

Sekolah Dasar Negeri 33 Pangkalpinang adalah sekolah penyelenggara pendidikan inklusi, peserta didik inklusi memerlukan layanan khusus dimana salah satu peserta didik yang diterima adalah anak dengan gangguan autisme. Autisma berasal dari kata autos yang berarti diri sendiri dan isme berarti paham. Ini berarti bahwa autisme memiliki makna keadaan yang menyebabkan anak-anak hanya memiliki dunianya sendiri. Penyandang autisma seakan-akan hidup di dunianya sendiri.

Pendidikan inklusi merupakan pelaksanaan amanah pemerintah yang telah diatur dalam Peraturan Menteri Pendidikan Nasional Republik Indonesia Nomor 70 
tahun 2009 tentang pendidikan inklusif bagi peserta didik yang memiliki kelainan dan memiliki potensi kecerdasan dan/atau bakat istimewa.

Terkait dalam layanan yang diberikan bagi peserta didik berkebutuhan ini meliputi: tunanetra, tunarungu, tunawicara, tunagrahita, tunadaksa, tunalaras, berkesulitan belajar, lamban belajar, autis, memiliki gangguan motorik, menjadi korban penyalahgunaan narkoba, obat terlarang, dan zat adiktif lainnya, memiliki kelainan lainnya dan tunaganda (Permendiknas RI No. 70 tahun 2009, pasal 3 ayat 2).

Belajar adalah salah satu faktor yang mempengaruhi dan berperan penting dalam pembentukan pribadi dan perilaku individu. Sukmadinata (2005: 16); menyebutkan bahwa sebagian terbesar perkembangan individu berlangsung melalui kegiatan belajar. Lantas, apa sesungguhnya belajar itu ?

Banyak ahli dalam memberi makna belajar seperti: Surya (1997: 36); menyatakan belajar dapat diartikan sebagai suatu proses yang dilakukan oleh individu untuk memperoleh perubahan perilaku baru secara keseluruhan, sebagai hasil dari pengalaman individu itu sendiri dalam berinteraksi dengan lingkungannya".

Perilaku individu mencakup segala pernyataan hidup, betapa banyak kata yang harus dipergunakan untuk mendeskripsikannya. Untuk keperluan studi tentang perilaku kiranya perlu ada sistematika pengelompokan berdasarkan kerangka berfikir tertentu (taksonomi).

Dalam konteks pendidikan, Bloom mengungkapkan tiga kawasan (domain) perilaku individu beserta sub kawasan dari masing-masing kawasan, yakni : (1) kawasan kognitif; (2) kawasan afektif; dan (3) kawasan psikomotor. Taksonomi perilaku di atas menjadi rujukan penting dalam proses pendidikan, terutama kaitannya dengan usaha untuk mencapai hasil pendidikan yang optimal. Segenap usaha pendidikan seyogyanya diarahkan untuk terjadinya perubahan perilaku peserta didik secara menyeluruh, dengan mencakup semua kawasan perilaku.

Autisme adalah gangguan perkembangan pervasif pada anak yang ditandai dengan adanya gangguan dan keterlambatan dalam bidang kognitif, bahasa, perilaku, komunikasi dan interaksi sosial, hal ini senada dengan apa yang dinyatakan oleh 
Sarasvati dimana autis merupakan bagian dari Pervasive Developmen Disorder adalah gangguan dalam perkembangan pertumbuhan seseorang dari segi interaksi sosial, komunikasi, perilaku yang kadangkala repetitif (berulang-ulang), terbatas (restricted) atau juga streotype (khas) (Sarasvati2004: 129).

Untuk memberikan layanan bagi peserta didik dengan perilaku autis memerlukan sistem pembelajaran tertentu dengan kondisi ini, dalam upaya untuk memberikan pendekatan layanan pembelajaran pendekatan yang dilakukan yaitu Discrete Trial Training (DTT): Training ini didasarkan pada Teori Lovaas yang mempergunakan pembelajaran perilaku. Dalam pembelajarannya digunakan stimulus respon atau yang dikenal dengan operand conditioning. Dalam prakteknya guru memberikan stimulus pada anak agar anak memberi respon. Apabila perilaku anak itu baik, guru memberikan reinforcement (penguatan). Sebaliknya perilaku anak yang buruk dihilangkan melalui time out/ hukuman/kata "tidak". Dengan harapan melalui pendekatan tersebut dapat membantu anak mengenal ingkungannya dalam Kurdi(2009: 18).

Tujuan yang diharapkan dalam penelitian ini yaitu untuk meningkatkan kepatuhan (bahasa reseptif memahami instruksi) siswa dalam kegiatan belajar. Dengan semakin sedikit intruksi dalam melakukan sesuatu tugas, semakin patuh anak terhadap instruksi dan semaikin baik pula pemahaman anak. Banyak metode belajar bagi anak, penulisan ini mempunyai tujuan menerapkan salah satu pendekatan pembelajaran bagi anak didik dengan autisme. Dan meningkatkan pemahaman guru terhadap pendekatan yang sesuai dan dapat diterapkan untuk anak didik.

\section{Metode Belajar}

Pendekatan DTT mempunyai ciri khusus dimana dalam setiap tahap pembelajaran dimulai dari adanya rangsangan (stimulus), supaya anak mau menerima rangsangan dan melakukan aksi yang sesuai harus ada stimulus tambahan (perintah), tanggapan (aksi) berupa perilaku atau respon dari stimulus dan perintah dan dalam setiap aksi anak diberikan konsekuensi atau penghargaan. Hal ini sesuai dengan pendapat Kurdi (2009) yaitu discrete trial adalah adalah unit instruksi yang terdiri dari antecendent, respon dan konsekuensi. 


\begin{abstract}
Alat Belajar
Alat pendidikan merupakan faktor yang dibuat dan disengaja disiapkan untuk mencapai tujuan pendidikan tertentu. Faktor alat ini dapat berupa situasi, kondisi, tindakan atau perlakuan yang diadakan secara sengaja.

L. Hendro Wibowo (dalam Sumitro, dkk, 1998: 80) menyebutkan bahwa lingkungan memberikan peran yang tidak sedikit dalam upaya mencapai tujuan pendidikan. Adapun komponen lingkungan ini yaitu: 1. Lingkungan fisik (keadaan iklim, keadaan alam). 2. Lingkungan Budaya (bahasa, seni, keadaan ekonomi, politik, pandangan hidup, keagamaan dan lainya), serta Lingkungan sosial/masyarakat (keluarga, kelompok bermain, organisasi).
\end{abstract}

\title{
Teknik Discrete Trial Training (DTT)
}

Discrete Trial Training adalah teknik terbaik dari analisisa tingkah laku (behavior Analysis) untuk meningkatkan keterampilan pada anak dengan autisme (Smith, 2001 dalam Kurdi, 2009). DTT mempunyai program membagi keterampilan yang sangat kompleks menjadi keterampilan dengan unit yang lebih kecil dan mengajarkanya dengan cara dipraktekkan berulang-ulang. Setiap unit yang diinstruksikan disebut a Trial (Leaf dan Mc Eachin, 1999 dalam Kurdi, 2009). Discrete dalam DTT dinamakan demikian karena setiap instruksional trial harus ada tanda mulai dan tanda berakhir (leaf dan MC Eachin, 1999 dalam Kurdi, 2009: 24).

Berdasar teori diatas teknik dalam penerapan DTT dilakukan dalam beberapa tahap yaitu: Analisis tingkah laku (Behavior Analysis) untuk meningkatkan keterampilan.Program membagi keterampilan yang sangat kompleks menjadi keterampilan dengan unit yang lebih kecil. Mengajarkanya dengan cara dipraktekkan berulang-ulang. Setiap instruksional trial harus ada tanda mulai dan tanda berakhir.

\section{Aspek perhatian dalam menggunakan Discrete Trial Training (DTT)}

Autisme merupakan spektrum sindroma kelainan neurologis yang tidak bisa disembuhkan. Dengan kelainan terutama adanya gangguan pada trias komunikasi, imajinasi dan interaksi sosial. Dengan berbagai modifikasi anak dengan autisme bisa 
ditingkatkan kemampuannya untuk berkomunikasi. Penanganan dan pembelajaran pada anak autis memerlukan team yang cukup kuat lengkap agar proses pembelajaran yang diharapkan bisa berhasil. Anak autis mempunyai kemampuan modalitas masing masing yang tidak sama satu sama lain. Dengan kondisi demikian maka program penanganan dan pembelajaran memerlukan modifikasi dimana satu anak dengan anak lainnya berbeda.

Tingkat keberhasilan pelaksanaan program pendidikan dan pengajaran pada anak autis dipengaruhi oleh beberapa faktor, antara lain:

1. Berat ringannya kelainan/gejala

2. Usia pada saat diagnosis

3. Tingkat kemampuan berbicara dan berbahasa

4. Tingkat kelebihan dan kekurangan yang dimiliki anak

5. Kecerdasan/IQ

6. Kesehatan dan kestabilan emosi anak, dan

7. Terapi yang tepat dan terpadu meliputi guru, kurikulum, metode, sarana pendidikan, lingkungan (keluarga, sekolah dan masyarakat) (Kurdi, 2009: 24).

Dasar pemikiran menggunakan Discrete Trial Training (DTT) karena kondisi masing-masing anak sangat berbeda, modal awal dan hasil akhir setiap individu akan sangat tergantung pada faktor kuantitas gejala autisme anak, intensitas penanganan dini, tingkat intelegensi anak, kemampuan anak berkomunikasi, konsistensi pola asuh dalam keluarga, sikap sekolah dalam membantu anak dan juga pengetahuan guru dapat menjadi faktor keberhasilan anak. Dengan kondisi demikian penerapan Discrete Trial Training (DTT) dalam pembelajaran dengan tahap yang tepat terencana dan tercatat, modalitas anak dapat dikembangkan secara lebih detil sesuai modalitas khusus anak. Peningkatan dan perkembangan anak menjadi dasar untuk menentukan program kelanjutan pembelajaran dan penanganan pada anak.

\section{METODE}

Metode penelitian yang digunakan dalam penelitian ini menggunakan pendekatan metode Penelitian Tindakan kelas (PTK). Menyatakan; efektifnya 
penelitian tindakan digunakan, dikarenakan dalam proses penelitiannya bersifat partisipatoris dan kolaboratif dimana proses perubahan metode dan strategi didasarkan pada kepedulian bersama terhadap keadaan yang perlu ditingkatkan. Orang-orang dalam situasi tertentu mendeskripsikan kepeduliannya, menjajagi apa yang dipikirkan orang lain, dan berusaha mencari apa yang mesti dilakukan untuk mengubah situasi. Kelompok terkait mengidentifikasi kepedulian tematik yang menentukan bidan subtansi yang akan menjadi yang akan menjadi fokus strategi peningkatan. Anggota kelompok menyusun rencana tindakan, bertindak, mengamati secara individual dan kolektif dan melakukan refleksi secara bersama-sama.

Model penelitian tindakan kelas dalam penelitin ini menggunakan model Kurt Lewin. Konsep pokok penelitian model Kurt Lewin terdiri dari empat komponen, yaitu: Perencanaan (planning), tindakan (acting), pengamatan (observing), dan refleksi (reflecting), hubungan keempat hal tersebut dipandang sebagai satu siklus (Kusumah dan Dwitagama, 2010: 325).

Untuk memperjelas runtutan kegiatan dalam penelitian ini dapat digambarkan dalam desain PTK dalam satu siklus model Kurt Lewin, adalah sebagai berikut:

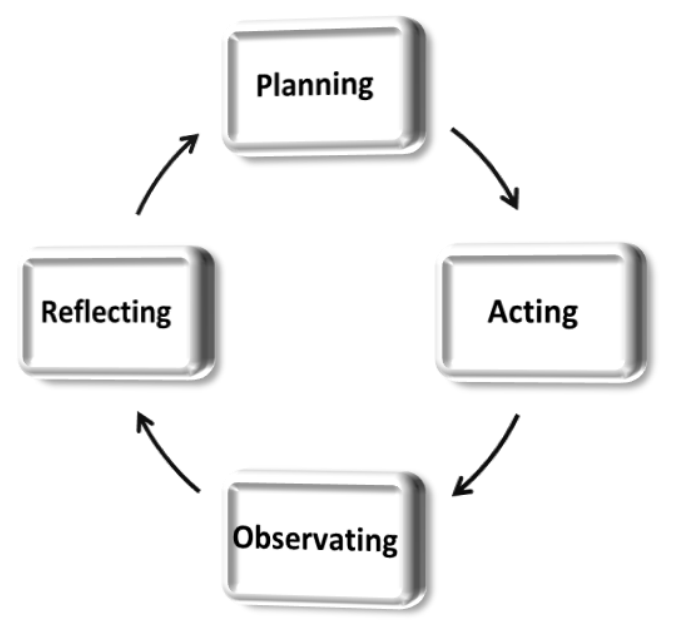

Gambar 1. Siklus PTK Model Kurt Lewin

Sebelum dilaksanakan penelitian, peneliti menyusun tahapan-tahap kegiatan penelitian tidakan kelas. Tahapan tahapan tersebut adalah:

1. Tahapan perencanaan tindakan perbaikan (planning) 
a. Pembuatan disain pembelajaran yang memuat Rencana Pelaksanaan Pembelajaran (RPP).

b. Persiapan sarana dan prasarana penelitian yang meliputi:

- Penyiapan ruangan khusus dengan ukuran tidak terlalu luas dengan warna yang redup.

- Setting sarana pembelajaran yang sesuai untuk pelaksanaan pembelajaran individual.

- Pembuatan media pembelajaran pokok

- Menyiapkan media pembelajaran penunjang

c. Indikator kinerja

Untuk melihat seberapa jauh keberhasilan pembelajaran yang diterapkan pada anak diperlukan alat ukur. Alat ukur disiapkan untuk menilai guru sebagai peneliti juga alat penilaian untuk anak sejauhmana materi terserap. Adapun alat yang akan digunakan untuk menilai kegiatan penelitian yaitu: lembar observasi kemampuan melaksanakan kegiatan pembelajaran, tally pengulangan kategori dalam satu pertemuan (untuk melihat tinngkat penerimaan intruksi), dan penilaian langsung yaitu penilaian berdasar pada tes sesuai dengan RPP.

2. Tahapan pelaksanaan tindakan (acting)

Kegiatan dilaksanakan berdasar pada RPP dimana ruang lingkup materi yang akan diberikan dimasukkan kedalamnya. Disertai alat evaluasi, dari hasil evaluasi ini akan dilakukan pengayaan untuk menentukan sejumah materi yang diberikan dapat diserap siswa, juga untuk menentukan materi yang akan diberikan pada pembelajaran selanjutnya.

Tindakan dilaksanakan berada diruang khusus dan diluar ruangan belajar. Diluar ruangan digunakan untuk memberikan dan mengevaluasi materi yang lebih efektif dilaksanakan di luar ruang berupa latihan dan praktik.

3. Tahapan pengamatan (observating)

a. Pembuatan instrumen atau kuesioner yang dibuat oleh guru yang akan dilakukan oleh observer. 
b. Pengumpulan data penelitian dari siklus pertama sampai dengan terakhir.

c. Seluruh data dicatat dalam tabel data penelitian tindakan kelas.

4. Tahapan refleksi

Tahap refleksi peneliti melaksanakan beberpa proses yaitu memperhatikan dari hasil observasi dan pengisian instrumen. Diskusi dengan teman sejawar yang berperan sebagai observer, untuk mendapatkan masukan yang bermanfaat. Selain itu peneliti juga mengunakan pertemuan bimbingan untuk berkonsultasi dengan pembimbing untuk mendapatkan masukan tentang hal-hal yang sudah dilakukan dan akan dilakukan setelah satu siklus dilaksanakan.

\section{HASIL PENELITIAN DAN PEMBAHASAN}

\section{Hasil Penelitian Kegiatan Pembelajaran}

Dengan mengikuti prosedur penelitian tindakan kelas (PTK) yang dimulai dari penyusunan rencana penlitian yang telah disetujui kepala sekolah, menyiapkan instrumen penelitian, menyiapkan ruang khusus yang digunakan untuk melaksanakan pembelajaran secara individual dalam ruang lingkup penelitian tindakan, maka peneliti dapat melaporkan hasil pelaksanaan penelitian. Sebelum pelaporan ini peneliti telah melakukan teknik pengumpulan data, menganalisis data bersama observer dan teman sejawat dalam pertemuan anggota kelompok penelitian, menafsirkan data, menarik kesimpulan, menentukan tindakan perbaikan pada setiap siklus. Berdasar dari pelaksanaan prosedur tersebut, peneliti akan menguraikan hasil yang sudah dicapai dalam melaksanakan penelitian tindakan kelas.

\section{KATEGORI}


A.02.Kontak mata selama dipanggil nama.

1. Kontak mata ketika sedang melakukan kegiatan.

B.01. IGM. Motorik kasar.

B.04. IGM. Mulut.

C.01. Mengikuti perintah sederhana.

C.02. Identifikasi bagian-bagian tubuh.

C.03. Identifikasi benda-benda di sekitar.

C.04. Identifikasi gambar dengan 2 distraksi.

D.03. Imitasi suara \& kata.

E.01. Matching bola dengan keranjang.

E.03. Identifikasi warna dengan 2 distraksi.

E.04. Identifikasi bentuk dengan 2 distraksi.

E.05. Identifikasi huruf dengan 2 distraksi.

F.03. Bina diri

Motorik halus

Play terapi

Gambar2. Materi pengamatan 


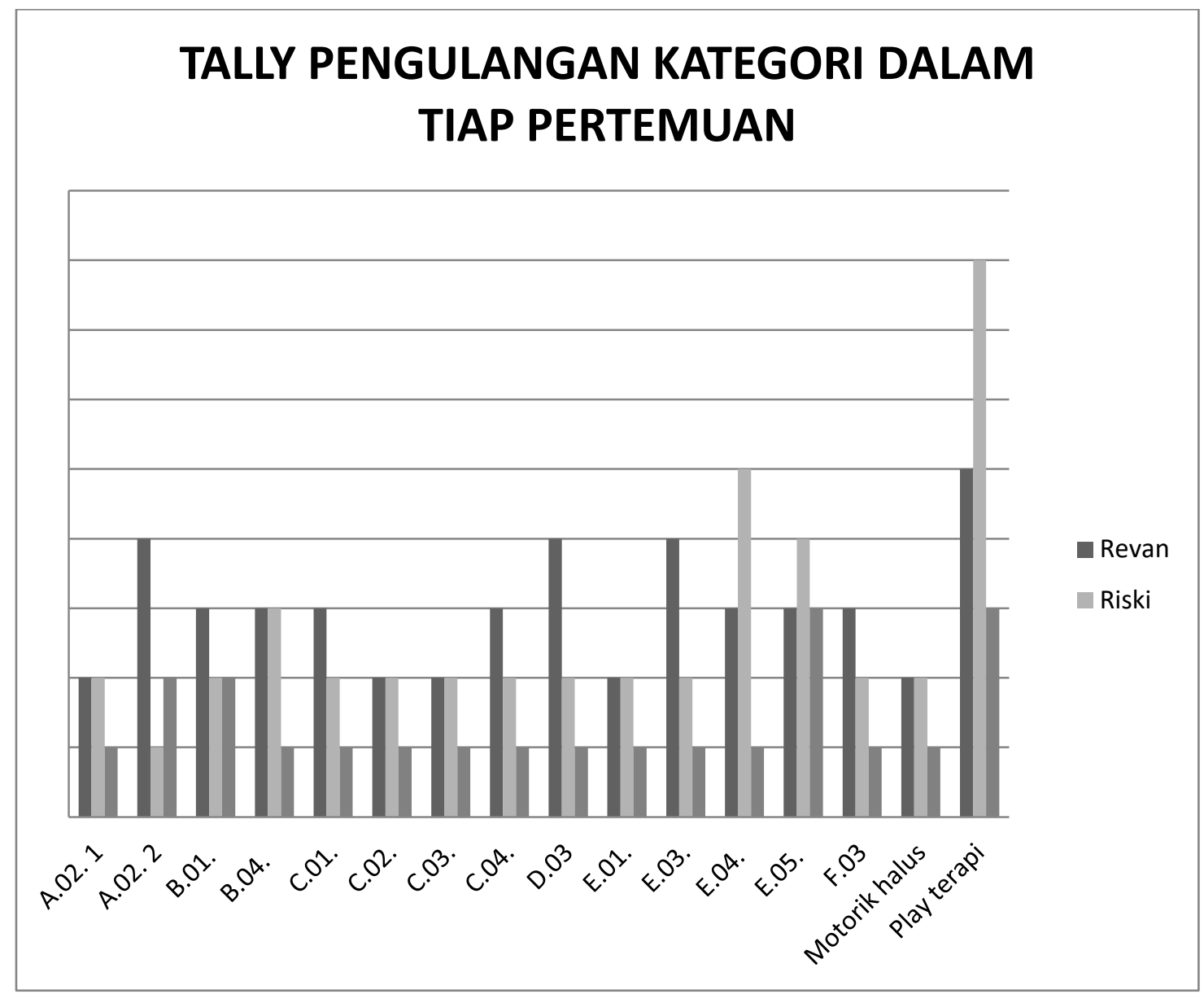

Gambar 3. Grafik Tally PengulanganKategori dalam TigaPertemuan

Semakin sedikit pengulangan yang dilakukan dalam DTT mempunyai hubungan pemahaman terhadap intruksi semakin baik. Pengulangan yang semakin sedikit menunjukan pula penguasaan terhadap materi terlihat lebih baik. Tabel berikut menunjukan perubahan penguasaan terhadap materi yang dipelajari siswa. 


\section{PENGUASAAN MATERI}

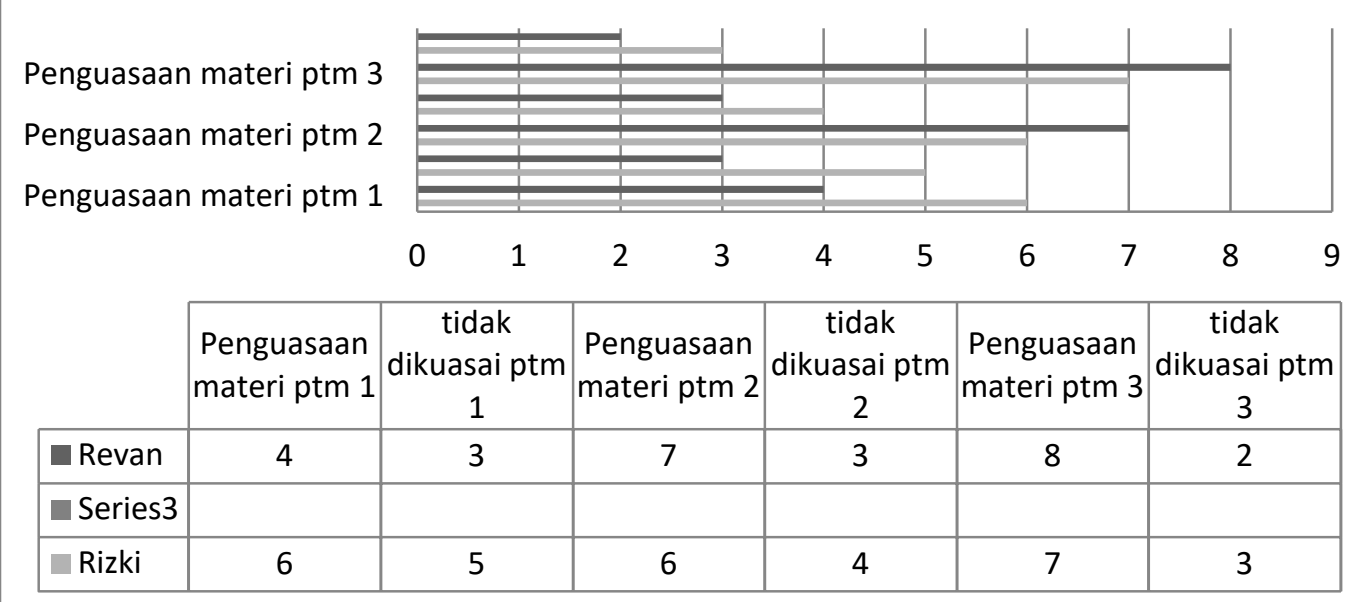

Gambar 4. Grafik Penguasaan Materi Siswa

\section{Pembahasan}

Kemampuan bahasa reseptif berkait erat dengan pemahaman. Dengan memahami intruksi yang disampaikan oleh orang semakin mudah anak melakukannya. Pemahaman bahasa reseptif harus dikuasai terlebih dahulu sebelum menggunakan bahasa ekpresif. Bagi anak dengan autisme dalam memahamkan intruksi (bahasa Reseptif) memerlukan strategi dan cara yang unik, serta dalam proses belajar harus dilakukan secara bertahap. Dengan mengikuti prosedur melalui pendekatan DTT beberapa proses yang dilalui yaitu:

1. Diawali dengan analisis tingkah laku (Behavior Analysis) untuk meningkatkan keterampilan inti yang akan dikembangkan.

2. Membagi keterampilan yang sangat kompleks menjadi keterampilan dengan unit yang lebih kecil.

3. Dalam mengajarkan dengan cara dipraktekkan berulang-ulang.

4. Setiap instruksional trial harus ada tanda mulai dan tanda berakhir.

Dengan melihat dari 3 siklus yang ditampilkan pada tabel 2 Grafik Tally pengulangan kategori dalam 3 pertemuan, terlihat adanya perubahan pengulangan yang semakin sedikit. Dalam A.02.Kontak mata selama dipanggil nama, pertemuan pertama dilakukan berulang ulang sampai 3 kali, perubahan dapat dilihat pada pertemuan ketiga cukup dengan satu panggilan anak dapat 
melakukan. ini menjunjukkan anak semakin paham dengan intruksi dan tujuan pembelajaran semakin tercapai.

Pada C.03. Identifikasi benda-benda di sekitar.mengenal benda sekitar melalui intruksi bagi anak autis bisa menjadi kendala, sebab penguasaan pemahaman terhadap kosakata yang sangat rendah. Untuk itu pembelajaran bahasa reseptif mengenal benda sekitar tidak luput sebagai materi belajar.

Perubahan pada penguasaan materi penguasaan materi berkaitan bahasa reseptif yang digunakan berarti anak semakin menguasai. Dengan pengulangan yang semakin sedikit menunjukan anak dapat memahami dan melaksanakan instruksi. kemampuan mengelola perhatian melihat, mendengar melakukan dengan bertahap menunjukan perubahan semakin efektif dan oemahaman terhadap kosa kata semain baik.

Dengan melihat data yang disajikan dari siklus I, siklus II dan siklus III terlihat adanya perubahan yang lebih baik. Perubahan pada penguasaan materi penguasaan materi berkaitan bahasa reseptif yang digunakan berarti anak semakin menguasai. Dengan pengulangan yang semakin sedikit menunjukan anak dapat melakukan instruksi dengan sedikit pengulangan. Dari hasil observasi kemampuan guru dalam mengelola kelas menjadi lebih berkualitas.

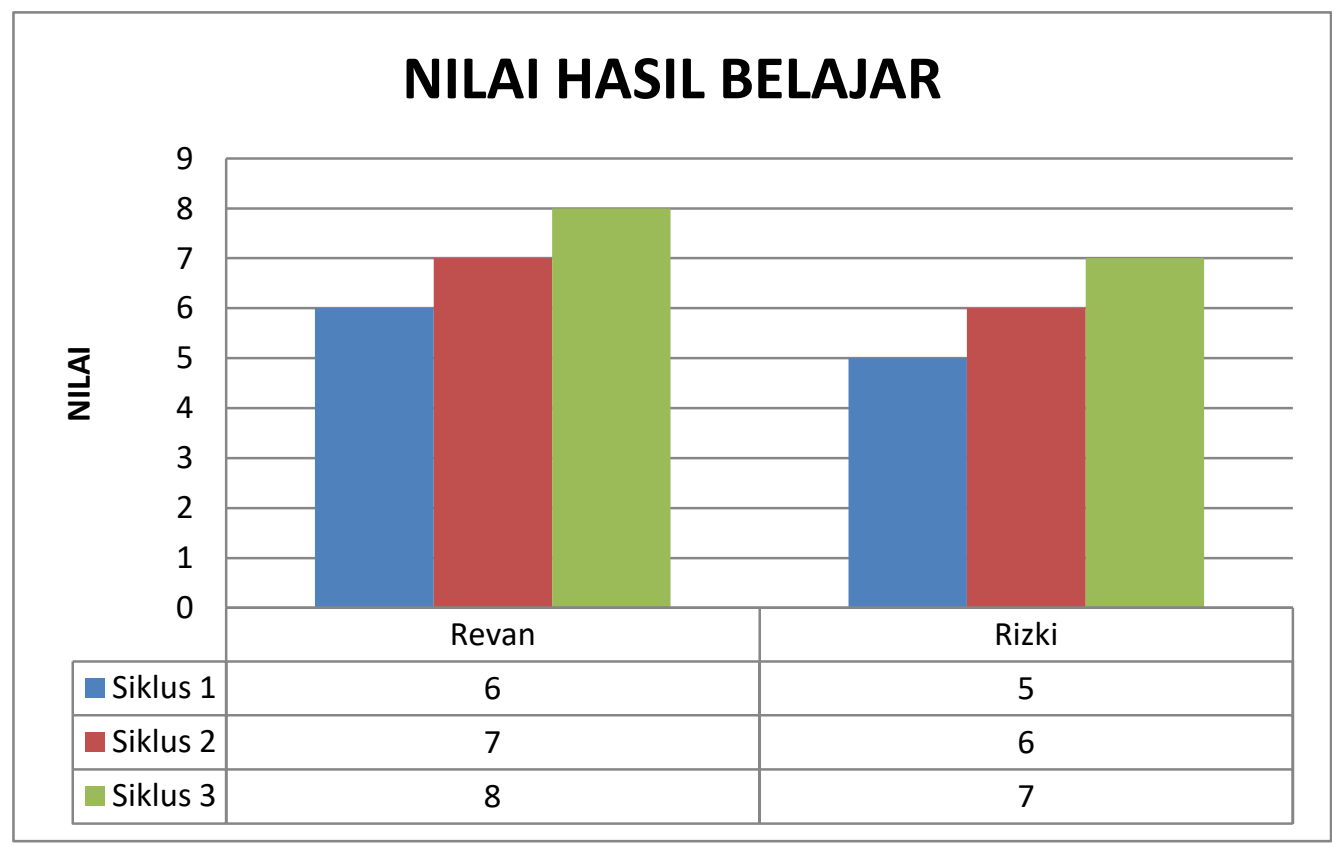

Gambar 5. Grafik Nilai Hasil Belajar 
Ketercapaian dilihat berdasar pada penguasaaan yang diberikan ditiap tahap pembelajaran. Materi diberikan secara bertahap setelah satu materi dapat dikuasai. Setiap stimulus dan respon anak didokumentasikan untuk mengetahui tingkat pengulangan dengan semakin sedikit pengulangan menyatakan pemahaman anak. Hasil yang diperoleh pada siklus I subyek Re dapat menguasai 6 dari 10 materi dan subyek Ri menguasai 5 materi dari 10 materi, pengulangan stimulus lebih dari 3 kali. Siklus II dilaksanakan dengan merubah stimulus berupa peningkatan reward hasil kegiatan subyek Re dapat menguasai 7 dari 10 materi dan subyek Ri menguasai 6 materi dari 10 materi, pengulangan stimulus rata rata 2 kali. Siklus III modifikasi berupa penyesuaian tekanan instruksi yang disesuaikan dengan respon anak subyek Re dapat menerima respon dengan nada yang lembut menguasai 8 dari 10 materi dan subyek $\mathrm{Ri}$ menguasai 7 materi dari 10 materi, pengulangan stimulus rata rata dibawah 2 kali. Dengan melihat pengulangan stimulus singkat dan respon yang cepat dan benar maka pembelajaran dianggap berhasil

\section{SIMPULAN}

Kegiatan pembelajaran dilaksanakan secara individual, bagi anak dengan autisme akan lebih mempermudah guru dalam pengelolaan kelas dan perilaku. Pemahaman guru terhadap keunikan yang dimiliki anak sangat menentukan tingkat keberhasilan tujuan belajar. Membuat suasana yang nyaman dalam kegiatan belajar membuat suasana pembelajaran menjadi kondusif.

Peningkatan pemahaman siswa terhadap instruksi yang diberikan guru mempunyai hubungan kuat terhadap daya dan pemahaman terhadap instruksi bahasa reseptif. Peningkatan yang terlihat menunjukan bahwa pendekatan pembelajaran dengan Pendekatan Discrete Trial Training (DTT) dapat meningkatkan kemampuan Bahasa Reseptif Anak dengan Autisme Kelas 1 di SD Negeri 33 Pangkalpinang. Secara eksplisit kemampuan dapat terlihat berupa hasil penamatan dan penilaian penguasaan namun secara implisit tentunya 
berkait langsung dengan seberapa anak dapat melaksanakan intruksi yang didengar dari siapapun.

\section{DAFTAR PUSTAKA}

Kurdi, F.N. (2009). Strategi dan Teknik Pembelajaran Pada anak dengan Autisme. Forum Kependidikan, Vol. 29, No. 1, pp: 14-25.

Kusumah, W. dan Dwitagama, D. (2010).Mengenal Penelitian Tindakan Kelas. Jakarta: PT Indeks.

Permendiknas RI No. 70 Tahun 2009 tentang Konsep Pendidikan Inklusif.

Sarasvati. (2004). Meniti Pelangi Perjalanan Seorang Ibu Yang Tak kenal menyerrah dalam membimbing putranya keluar dari belenggu ADHD dan Autisme. Jakarta: PT Elex Komputindo.

Sukmadinata. N.S. (2005). Landasan Psikologi Proses Pendidikan, Bandung; PT Rosda Karya.

Sumitro, dkk. (1998). Pengantar Ilmu Pendidikan. Yogyakarta: Fakultas Ilmu Pendidikan UNY.

Surya M. (1997), Psikologi Pembelajaran dan Pengajaran, Bandung: PPB IKIP Bandung.

Madya S. (1994). Seri Metodologi Penelitian. Panduan Penelitian Tindakan. Lembaga Penelitian IKIP Yogyakarta. 